\title{
Analisis Kohesi Leksikal Pada Berita Olahraga di Surat Kabar Solopos Edisi Oktober 2019
}

\author{
Siti Aminataz Zuhriyah \\ Institut Agama Islam Negeri (IAIN) Surakarta \\ sitiaminatazzuhriyah@gmail.com
}

\begin{abstract}
The study entitled "Analysis of Lexical Cohesion in Sports News in the October 2019 Solopos Newspaper" aims to describe or analyze lexical cohesion contained in the October edition of the Solopos newspaper. The method used in this study is a descriptive qualitative method. This method is a research method that seeks to describe objects according to their actual circumstances. There are five stages in this study, namely the stages of reading newspaper texts, coding the data in accordance with the theory, identifying, clarifying, and concluding and presenting data. The data of this study is a collection of the October 2019 edition of the Solopos rubric soccer newspaper. The results of this study indicate that of the six types of lexical cohesion that are often found in Solopos newspapers are repetition or iteration.
\end{abstract}

Keywords: Lexical cohesion, newspaper news texts, Solopos newspapers

Abstrak. Penelitian yang berjudul "Analisis Kohesi Leksikal pada Berita Olahraga di Surat Kabar Solopos Edisi Oktober 2019" bertujuan untuk mendeskripsikan atau menganalisis kohesi leksikal yang terdapat dalam koran Solopos edisi Oktober. Metode yang digunakan dalam penelitian ini adalah metode deskriptif kualitatif.Metode ini merupakan metode penelitian yang berusaha menggambarkan objek sesuai dengan keadaan yang sebenarnya. Ada lima tahapan metode dalam penelitian ini yaitu, tahapan membaca teks koran, pengkodean pada data yang sesuai teori, mengidentifikasi, mengklarifikasi, dan menyimpulkan serta menyajikan data. Data penelitian ini kumpulan koran sepak bola rubric Solopos edisi Oktober 2019. Hasil penelitian ini menunjukkan bahwa dari enam jenis kohesi leksikal yang ada dalam surat kabar Solopos yang sering ditemukan adalah repetisi atau pengulangan sedangkan lima jenis lainnya tidak sering ditemukan dalam surat kabar Solopos.

ESTETIK : Jurnal Bahasa Indonesia, vol. 3, no. 1, 2020

IAIN Curup - Indonesia | ISSN 2622-1810 (p); 2622-1829 (e)

DOI: $10.29240 /$ estetik.v3i1.1481 
Kata kunci: Kohesi Leksikal, teks berita koran, surat kabar Solopos

\section{Pendahuluan}

Media merupakan bagian kehidupan masyarakat yang tidak bisa dipisahkan dalam kehidupan sehari-hari. Media juga merupakan bagian terpenting dalam proses maupun sarana perkembangan masyarakat untuk menyampaikanberita informasi dan pengetahuan yang lebih luas. Dalam pembagiannya, media dibagi menjadi dua bagian, yaitu media elektronik dan media cetak.Media elekronik diantaranya adalah radio, televisi, dan film. Sedangkan, media cetak diantaranya adalah spanduk, majalah, poster, dan surat kabar.

Selain media elektronik, media lain yang masih diminati masyarakat sampai sekarang ini adalah media cetak seperti surat kabar. Solopos merupakan media cetak koran atau surat kabaryang paling populer di daerah Solo, Solopos menginformasikan berita localseputar solo raya dan sekitarnya.Oleh karena itu, penelitian ini penting dilakukan karena akan mempermudah masyarakat dalam memahami makna wacana yang ada dalam sebuah surat kabar Solopos. Meskipun demikian, Solopos juga menyediakan portal untuk melayani netizen seputar Semarang Raya, Madiun Raya, dan Jogjapolitan.Teks berita yang disediakan pun sangat beragam, salah satunya adalah berita mengenai olahraga. Di dalam rubrik tersebut, terdapat informasi-informasi yang memuat berita seputar kawasan solo raya seperti kota Solo, Wonogiri, Sragen, Klaten, Sukoharjo, Boyolali, Surakarta, Karanganyar. Berita tersebut memuat terkait adanya informasi seputar berita olahraga, berita politik nasional, pendidikan, pemerintahan, ekonomi, bisnis, makanan, sosial dan kesehatan.

Sebagai bagian dari media penyampaian informasi "Solopos" harus memiliki kesatuan atau keutuhan dalam tulisan yang mencerminkan ide atau permasalahan yang ingin diungkapkan oleh penulis. Sehingga informasi atau semua hal yang ingin disampaikan tim redaksi dapat dimengerti oleh pembaca (Simarmata, 2014). Meskipun demikian, hal yang pertama dalam pengolahan informasinya adalah konteks leksikal dalam penyampaian informasi kepada khalayak umum. Pembaca akan mudah memahami dan memaknai suatu wacana atau 
berita dengan bahasa ataupun kata yang sesuai dengan unsur berita yang sesuai di surat kabar Solopos.

Harian media cetak Solopos yang digunakan dalam pembahasan ini adalah rubrikolahraga khususnya tema Sepak Bola edisi Oktober 2019 yang diterbitkan oleh tim redaksi Solopos yang terdiri dari berbagai informasi seputar sepakbola Solo Raya seperti Klaten, Boyolali, Surakarta, Sukoharjo, Wonogiri, Sragen, dan Karanganyar. Dengan demikian, rubrik Olahraga di surat kabar Solopos menarik untuk dikaji menggunakan analisis wacana karena rubrik ini mudah ditemukan dalam setiap harinya sehingga pembaca memerlukan analisis wacana untuk mempermudah makna dalam wacana yang ada pada rubrik olahraga ini. Chaer (2012:267) menyatakan bahwa wacana merupakan satuan bahasa yang mempunyai tingkat kedudukan gramatikal tertinggi dalam suatu bahasa. Dalam hal ini, tentunya dibutuhkan peranti yang utuh untuk memahami makna suatu wacana.

Kohesi mempunyai peran penting untuk membantu pembaca menafsirkan suatu wacana (Dwinuryati : 2017). Kohesi tidak hanya berhubungan dengan bentuk saja (kohesi gramatikal) tetapi kohesi juga berhubungan dengan suatu makna (kohesi leksikal). Kohesi leksikal adalah hubungan leksikal diantara bagian wacana untuk mendapatkan keserasian struktur secara kohesif. Unsur kohesi leksikal terdiri dari sinonim (persamaan), antonim, hiponim, repetisi, kolokasi dan ekuivalensi. Penggunaan aspek-aspek leksikal ini diantaranya ialah untuk mendapatkan efek makna bahasa, kejadian informasi, dan keindahan bahasa lain (Mulyana: 2005).

Surat kabar Solopos dipilih sebagai objek penelitian dengan alasan bahwa surat kabar ini merupakan surat kabar yang cukup populer di wilayah Solo Raya. Banyak rubrik yang terdapat dalam surat kabar ini, salah satunya yakni rubrik olahraga yang terbit setiap hari pada halaman dua belas. Penelitian ini difokuskan pada analisis leksikal dalam berita olahraga di surat kabar solopos edisi oktober 2019 dengan menggunakan analisis leksikal berupa kolokasi, hiponimi, ekuivalensi, sinonimi, antonimi dan repetisi. 
Penelitian yang membahas mengenai analisis wacana leksikal dalam surat kabar pernah dilakukan oleh Silvina (2015) dengan judul Kohesi Leksikal pada Wacana Opini Surat Kabar Harian Solopos Edisi Februari 2015. Hasil penelitian tersebut menunjukkan bahwa ada beberapa jenis kohesi leksikal yang terdapat pada wacana opini surat kabar harian solopos, yaitu ulang penuh, ulangan dengan bentuk lain, ulangan dengan penggantian, ulangan dengan hiponim, dan kolokasi. Sedangkan kohesi leksikal yang paling dominan keluar yaitu bentuk ulang penuh yakni sebanyak 43 kata. Persamaan penelitian tersebut dengan penelitian sekarang yaitu sama-sama menganalisis kohesi leksikal pada surat kabar, dan perbedaannya terletak pada jenis rubriknya. Dimana penelitian tersebut meneliti rubrik wacana opini dan penelitian sekarang meneliti rubrik olahraga.

Selain itu, Simarmata dalam penelitiannya yang berjudul Analisis Unsur Leksikal dalam Wacana pada Surat Kabar Tribun Pontianak Rubrik "Borneo Sport" (Edisi, 16 Mei-21 Mei 2014) menunjukkan bahwa penggunaan unsur leksikal dalam harian Tribun Pontianak tidak begitu banyak, yakni hanya sinonimi dan reduplikasi saja. Persamaan penelitian tersebut dengan penelitian sekarang yaitu sama-sama menganalisis kohesi leksikal pada wacana olahraga, dan perbedaannya terletak pada jenis surat kabar yang diteliti. Penelitian tersebut meneliti pada surat kabar tribun Pontianak dan penelitian sekarang meneliti pada surat kabar Solopos.

Sama halnya dengan Parwati (2010) dalam penelitiannya yang berjudul Kohesi Leksikal Repetisi pada Wacana "Wayang Durangpo" dalam Surat Kabar Harian Jawa Pos Edisi Februari-April 2010 menunjukkan bahwa ada lima jenis repetisi yang terdapat dalam wacana "Wayang Durangpo" yaitu repetisi epizeuksis (pengulangan kata secara langsung), repetisi anafora (pengulangan kata pada awal kalimat), repetisi epistrofa (pengulangan kata pada akhir kalimat), repetisi mesodiplosis (pengulangan kata di tengah kalimat), dan repetisi anadiplosis (pengulangan kata di akhir kalimat yang menjadi kata pertama pada kalimat berikutnya). Persamaan penelitian tersebut dengan penelitian sekarang yaitu sama-sama menganalisis kohesi leksikal pada surat kabar, dan perbedaannya terletak pada jenis 
rubriknya.Penelitian tersebut meneliti rubrik wacana wayang dan penelitian sekarang meneliti rubrik olahraga.

Berdasarkan uraian diatas, penelitian ini bertujuan untuk mengetahui penggunaan penanda kohesi yakni kohesi leksikal pada berita olahraga di surat kabar Solopos edisi Oktober 2019. Penelitian ini termasuk penelitian dalam jenis penelitian deskriptif kualitatif. Dikatakan demikian karena penelitian kualitatif merupakan bentuk penelitian yang berusaha menjelaskan fenomena-fenomena yang ada sesuai dengan kenyataan yang sebenarnya.Sumber data rubricsepak bola pada surat kabar Solopos edisi Oktober 2019. Data berupa teks wacana berita pada rubrik olahraga khususnya sepak bola pada surat kabar Solopos edisi Oktober yang berjumlah dua belas koran dengan dua puluh empat teks wacana berita (Solo Raya dan sekitarnya). Teknik yang digunakan dalam penelitian ini teknik analisis dokumentasi. Dokumentasi yang diperoleh pada penelitian ini adalah wacana berita yang terdapat pada rubrik olahraga sepak bola Solopos edisi Oktober 2019, koran yang dijadikan bahan penelitian ini dipilih secara acak dari tanggal 01 Oktober hingga tanggal 30 Oktober 2019. Analisis data yang dilakukam penulis meliputi beberapa langkah sebagai berikut: (1) membaca dua puluh empat teks wacana berita rubriksepak bola Solopos edisi Oktober 2019. (2) pengkodean, dilakukan dengan cara memberi tanda untuk setiap wacana berita, agar memudahkan peneliti dalam menganalisis data nantinya. (3) mengidentifikasi penanda kohesi leksikal apa saja yang digunakan dalam teks wacana berita rubrik Sepak Bola pada Solopos edisi Oktober 2019. (4) mengklarisifikasi mengenai penanda kohesi dalam teks wacana berita rubrik sepak bola Solopos edisi Oktober 2019. (5) membuat kesimpulan berdasarkan dari hasil analisis teks wacana berita rubik sepak bola Solopos edisi Oktober 2019.

Keabsahan data dilakukan dengan triangulasi dalam upaya mendapatkan keabsahan data penelitian.Dilakukan dengan pengecekan menggunakan buku-buku wacana.Buku wacana yang digunakan untuk pengujian keabsahan data didasari dari teori-teori yang menunjang penelitian ini yang dilakukan oleh peneliti. Serta validasi data dilakukan oleh dosen pembimbing selama proses bimbingan berlangsung dan diskusi dengan teman sejawat dalam menganalisis penggunaan peranti 
kohesi dan dalam rubrik sepak bola Solopos edisi Oktober 2019 (Apreno Reci, dkk. 2018).

\section{Hasil dan Pembahasan}

Hasil penelitian ini menunjukkan penulis rubrik sepak bola Solopos edisi Oktober 2019 menggunakan berbagai unsur peranti kohesi leksikal. Dari dua belas koran dan dua puluh empat teks wacana berita rubrik Sepak Bola Solopos yang menjadi objek penelitian, terdapat peranti kohesi leksikal yang bervariasi. Dengan adanya penelitian ini, diharapkan dapat memberikan kontribusi pengetahuan, pembelajaran, penelitian terkait kohesi leksikal pada surat kabar. Berikut ini penjabaran penggunaan peranti kohesi dalam wacana berita sepak bola Solopos edisi Oktober, peranti kohesi yang digunakan yaitu peranti kohesi leksikal.Peranti kohesi leksikal meliputi repetition (pengulangan), sinonimi, antonim, hiponimi, ekuivalensi, dan kolokasi. Kohesi leksikal berupa repetisi atau pengulangan seperti pada contoh berikut, yaitu:

\section{Kohesi leksikal (repetisi) pengulangan}

Menurut (Imran, Indiyah dkk, 2009: 27) kolokasi adalah kecenderungan sejumlah kata untuk bergabung secara teratur dalam suatu bahasa. Berikut ini unsur kohesi leksikal repetisi (pengulangan) yang terdapat dalam majalah Solopos edisi Oktober 2019.

(1) Apalagi kali ini Dortmund tak akan diperkuat kapten mereka, MarcoReus karena sakit. Sejauh ini, Reus menjadi andalan utama Lucien Fare...

Pada data (1) terdapat pengulangan kata Reus, Marco Reus karena sakit.Sejauh ini, Reus menjadi andalan utama Lucien Fare. Pengulangan nama tersebut termasuk dalam kategori pengulangan penuh.

(2) Inter tercatat Cuma menang sekali dalam tujuh laga kandang terakhirnya melawan tim Jerman. . . Namun, bukannya Inter tak punya peluang untuk mencetak kemenangan.

Pada data (2) terdapat pengulangan kata Inter, Inter tercatat Cuma menang sekali dalam tujuh laga kandang terakhirnya melawan tim Jerman. . .Namun, bukannya Inter tak punya peluang. Pengulangan nama tersebut termasuk dalam kategori pengulangan penuh. 
(3) Lee Kang-in pemain asal Korea Selatan (Korsel) yang masih berusia 18 tahun ... Leemenjadi satu-satunya pemain Asia yang akan bersaing ...

Pada data (3) terdapat pengulangan kata Lee Lee Kang-in pemain asal Korea Selatan (Korsel) yang masih berusia 18 tahun ... Lee menjadi satu-satunya pemain. Pengulangan nama tersebut termasuk dalam kategori pengulangan penuh.

(4) Daftar finalis Golden Boy 2019 telah diumumkan. Selasa, 15 Oktober, Golden Boy adalah penghargaan untuk pemain ...

Pada data (4) terdapat pengulangan kata Golden Boy, finalis Golden Boy 2019 telah diumumkan. Selasa, 15 Oktober, Golden Boy. Pengulangan nama tersebut termasuk dalam kategori pengulangan penuh.

(5) ...Sanksi yang diberikan FIFA tersebut. FIFA menjatuhkan sanksi kepada...

Pada data (5) terdapat pengulangan kata FIFA, ..Sanksi yang diberikan FIFA tersebut.FIFA menjatuhkan sanksi kepada . Pengulangan nama tersebut termasuk dalam kategori pengulangan penuh.

(6) ... Real Madrid, karena Gareth Bale dan Luka Modric cedera. Gareth Bale mencetak gol untuk...

Pada data (6) terdapat pengulangan kata Gareth Bale, karena Gareth Bale dan Luka Modric cedera.Gareth Bale mencetak gol untuk ... Pengulangan nama tersebut termasuk dalam kategori pengulangan penuh.

(7) ... Belum ada konfirmasi dari kedua tim dan juga dari Real Madrid soal cedera kedua pemain itu.

Pada data (7) terdapat pengulangan kata kedua tim, Belum ada konfirmasi dari kedua tim dan juga dari Real Madrid soal cedera kedua pemain itu. Pengulangan nama tersebut termasuk dalam kategori pengulangan pergantian.

(8) Milan ... kemenangan Al Milan atas gelar akhir pecan lalu belum memberikan jaminan...

Pada data (8) terdapat pengulangan kata Milan, Milan . . . kemenangan Al Milan atas gelar akhir pecan lalu belum memberikan jaminan. Pengulangan nama tersebut termasuk dalam kategori pengulangan penuh. 
(9) Direktur Milan ... dengan Giam Paole dan berniat segera memecat sang pelatih. Namun,....Paole

Pada data (9) terdapat pengulangan kata Paole, dengan Giam Paole dan berniat segera memecat sang pelatih. Namun, . . . .Paole. Pengulangan nama tersebut termasuk dalam kategori pengulangan penuh.

\section{Kohesi Leksikan Sinonimi}

Menurut Christian Baylon (2005: 109) sinonimi menggambarkan sebuah hubungan diantara dua kata atau dua pernyataan yang memiliki makna sama, atau lebih mudah dipahami dengan persamaan kata. Berikut ini unsur kohesi leksikal sinonimi yang terdapat dalam majalah Solopos edisi Oktober 2019.

(10) (10) Pada tahun 2018, Matthijs De Light terpilih sebagai pemain terbaik setelah iatampil ... Sementara itu Ansu Fati berhasil mencuri perhatian berkat performa...

Pada data (10) terdapat sinonim kata tampil dan performa, karena keduanya memiliki makna menampakkan diri atau muncul. Meskipun tidak memiliki persamaan kata yang hamoir mirip, dapat disimpulkan bahwa tidak ada kata yang sama mutlak.

(11) Beberapa pemain utama MU kemungkinan absen dalam laga tersebut. ... sedangkan Diogo dallot dan Angel Gomes juga diragukan bisa tampil di Den Haag.

Pada data (11) terdapat kata absen dan diragukan, karena keduanya memiliki makna meninggalkan lapangan. Meskipun tidak memiliki persamaan kata yang hampir mirip, dapat disimpulkan bahwa tidak ada kata yang sama.

(12) Pelatih AZ Alkmaar, arne, slot, ... sudah menang. Jia timnya bisa selamat dari kekalahan ditiga laga ....

Pada data (12) terdapat kata menang dan selamat dari kekalahan, karena keduanya memiliki makna memenangkan dan aman. Meskipun tidak memiliki persamaan kata yang hampir mirip, dapat disimpulkan bahwa tidak ada kata yang sama.

\section{Kohesi Leksikal Antonim}


Menurut Keraf (2010: 39), Antonim adalah relasi antar makna yang wujud logisnya sangat berbeda atau bertentangan. Antonimi bisa juga disebut perlawanan kata .Berikut ini unsur kohesi leksikal antonimi yang terdapat dalam majalah Solopos edisi Oktober 2019.

(13) Total Manager asal Jerman itu mencatatkan empat kali imbang dan sekali kalah.

Pada data (13) terdapat satu antonim yaitu kata imbang dan kalah.Kata imbang berarti menunjukkan kesamaan dalam bermain.

\section{Kohesi Leksikal Hiponimi}

Menurut Yuwono (2005: 99) hiponimi adalah hubungan antara kata yang bermakna spesifik dan kaya yang maknanya generic.Berikut ini unsur kohesi leksikal hiponimi yang terdapat dalam majalah Solopos edisi Oktober 2019.

(14) Ini artinya, kini pertahanan $M U$ cukup baik dalam meredam serangan Liverpool.

Pada data (14) terdapat hiponim kata MU, Liverpool karena bagian dari namaPersatuan Sepak bola Seluruh Indonesia (PSSI).

(15) Dari tujuh laga yang dijalani di liga seri AItalia, gawang samr Handanovic baru kebobolan dua gol. Tak ada tim lagi dari lima tiga top eropa yang punya catatan kebobolan...

Pada data (15) terdapat hiponim kata Liga seri- A dan lima liga top eropa karena bagian dari hiponim tersebut yang sama dalam hal makna.

(16) $M U$ ditunggu klub asal Belanda, Alkamar Zaanstreek (AZ) di stadion cars jeans, den high, kamis (3//10) pukul 23.55 WIB. Anak asuh Ole gunnar Solsk jaer berburu kemenangan ...

Pada data (16) terdapat hiponim kata MU dan Anak asuh Ole Gunna Solsk Jaer yang memiliki kemiripan makna dalam hal grup dalam sepakbola.

(17) Dengan pengalaman segudang sebagai wasit internasional, Conte menilai skomia seharusnya bisa member kepemimipinan ...

Pada data (17) terdapat hiponimi kata wasit internasional dan Conte dalam makna yang sama pada penamaan pelatih sepak bola. 
(18) Namun, perseimbangan lin pertahanan Inggris dipertanyakan apabila bermain dengan tiga bek belajar.John stones yang menjadi tandem sehati Meguire dan Kyle Walker maish dibelit cidera. Walker tidak dipanggil karena Soultgage lebih memilih Michael Keane dan Kierran Trippier.

Pada data (18) terdapat hiponimi kata tiga bek bek belajar, John stones, Kyle Walker, dan Walker dalam makna yang sama mengarah pada nama-nama pemain sepakbola.

\section{Kohesi Leksikal Kolokasi}

Menurut Yuwono (1992: 100) bahwa kolokasi adalah hubungan antar kata yang berada pada lingkungan atau bidang yang sama. Berikut ini unsur kohesi leksikal kolokasi yang terdapat dalam majalah Solopos edisi Oktober 2019.

(19) Pendukung Indonesia melempari tribune Supporter Ultras, Malaysia dengan berbagai benda.

Pada data (19) kata pendukung, tribun,dan supporter merupakan kolokasi, karena berada di ruang lingkup sepak bola.

(20) Sesuai laga, kerusuhan kembali pecah. Hal tersebut membuat para pendukung Harimau Malaysia harus ... meninggalkan stadion.

Pada data (20) kata laga, pendukung, dan stadion merupakan kolokasi, karena berada pada di ruang lingkup sepak bola.

(21) Bale yang terlihat sedikit pincang tetap berada di lapangan lantaran Wales sudah melakukan tiga pergantian.

Pada data (21) kata pincang, lapangan, dan pergantian merupakan kolokasi karena berada pada satu tempat sepak bola atau stadium.

(22) Nezzuri juga Cuma kebobolan tiga gol jika ditotal dengan ajang lain. Hanya paris sains-germain yang mendekati pencapaian intern dengan hanya kebobolan empat gol di semua kompetisi. Tim kuat asal Inggris, Mancheser City dan Liverpool sama-sama telah kemasukan tujuh gol.

Pada data (22) kata Mancheser City dan Liverpool merupakan kolokasi karena pada satu kesatuan nama grup sepakbola.

(23) Sepanjang pertandingan, Conte beberapa kali memprotes Sekomina dari pinggir lapangan. Mantan pelatih Juventus itu menilai wasit terlalu mengistimewakan tuan rumah dan kurang menghormati para pemainnya. 
Pada data (23) kata memprotes dan kurang menghormati merupakan kolokasi karena pada satu lingkup kondisi sepak bola.

(24) Lini pertahanan menjadi sector yang paling disorot ketika Inggris takluk dari Lukas Masopust dkk. Lini belakang Iggris membuat kesalahan elementer sehingga menyebabkan dua gol republic Cheska lahir. Southgate mengisyaratkan akanmengubah konsep bertahan alih-alih hanya mengganti pemain yang bersalah.

Pada data (24) kata kesalahan elementer dan mengubah konsep merupakan kolokasi karena tetap pada kesatuan sepak bola.

(25) sedangkan Pogba masih melanjutkan proses pemulihan cederaa pergelangan kaki. Pogba melewatkan jeda internasional untuk menjalani perawatan di Dubai.“David (Dedea) membutuhkan pemindaian.Saya rasa dia akan absen," ujar Solskjaer seperti dilansir Sky Sports.

Pada data (25) kata pemulihan dan pemindahan merupakan kolokasi karena tetap pada satu kesatuan dalam lapangan.

\section{Kohesi Leksikal Ekuivalensi}

Menurut Sudaryat (2011:162) Ekuivalensi adalah penggunaan kata-kata yang memiliki kemiripan makna atau maknanya berdekatan Berikut ini kohesi leksikal ekuivalensi yang terdapat dalam majalah Solopos edisi Oktober 2019.

(26) Klasemen Grup F . . kekalahan ini membuat Nicola Barellah dkk. Terdampar di dasar Klasemen grup F.

Pada data (26) terdapat ekuivalensi kata klasemen atau lebih dikenal dengan kata regu memiliki kedekatan makna atau identik dengan kekalahan.Bukan hanya sekelompok regu saja tetapi mengarah pada pertandingan yang berujung kalah atau menang.

(27) Tim Inter mencatat menang sekali dalam tujuh laga kandang terakhirnya melawan Tim Jerman.

Pada data (27) terdapat ekuivalensi kata menang yang memiliki kedekatan makna atau identic dengan melawan.Bukan hanya kata menang atau kalah, dalam sebuah pertandingan tentu ada perlawanan yang terjadi.

(28) Sebagai pengganti, Solskjaer bakal menurunkan Sergio romero. Ini adalah laga pertama romero musim ini dilaga primer. Sebelumnya kipper asal Argentina itu hanya bermain diliga Europa dan piala liga. Posisi pogba 
kemungkinan bakal diganti gelandang muda Scott McTominay yang penampilanya masih cenderung angina-anginan.

Pada data (28) terdapat ekuivalensi kata pengganti dan diganti yang memiliki kedekatan makna yang sama. Semua memiliki kedekatan makna pengganti.

\section{Kesimpulan}

Berdasarkan data hasil analisis di atas, dapat diketahui bahwa dalam informasi media cetak Solopos edisi Oktober 2019 terdapat enam jenis atau macam kohesi leksikal yaitu, kolokasi, sinonimi, antonimi, ekuivalensi, hiponimi dan (repetisi) pengulangan. Diantara jumlah kohesi leksikal pada koran Solopos edisi Oktober 2019 meliputisembilan repetisi (pengulangan), tiga kohesi leksikal sinonimi, satu kohesi leksikal antonimi, lima kohesi leksikal hiponimi, tujuh kohesi leksikal kolokasi, dan tiga kohesi leksikal ekuivalensi. Namun dalam menginformasikan kepada public atau khalayak umum kohesi leksikal yang paling sering digunakan dalam media informasi media cetak Solopos adalah repetisi pengulangan.Dengan demikian, dalam memberikan informasi kepada pembaca, media cetak cenderung lebih menggunakan repetisi atau pengulangan untuk memudahkan pembaca dalam memaknai sebuah kejadian yang lebih mudah untuk dipahami.

Penelitian ini diharapkan dapat bermanfaat untuk memberikan konstribusi pengetahuan, sumber pembelajaran terkait analisis wacanana, sebagai bahan referensi pada penelitian yang akan datang pada para penulis generasi baru. Selain itu, bab ini juga dapat dimanfaatkan untuk menyampaikan saran-saran terkait dengan penelitian.

\section{Daftar Pustaka}

Chaer, Abdul. 2012. Linguistik Umum. Yogyakarta: Rineka Cipta.

Baylon, Christia. 2005. Initation a la Semantique du Langgage. Paris: Armand Colin.

Imran, Indiyah dkk. 2009. "Kolokasi Bahasa Indonesia" dalam jurnal PESAT, 3 (3).

Mulyana. 2005. Kajian Wacana: Teori, Metode, dan Analisis prinsip 
Analisis Wacana. Yogyakarta: Tiara Wacana.

Parwati, Edin. 2010. "Kohesi Leksikal Repetisi pada Wacana 'Wayang Durangpo' dalam Surat Kabar Harian Jawa Pos Edisi FebruariApril 2010", dalam Jurnal Artikulasi, 12 (2).

Simarmata, M. Y. (2014). Analisis Unsur Leksikal dalam Wacana pada Surat Kabar Tribun Pontianak Rubrik 'Borneo Sport' Edisi 16 Mei- 21 Mei 2014" dalam Jurnal Pendidikan Bahasa, 3 (2),.

Sarii, Silvina Amilda. 2015. "Kohesi Leksikal pada Wacana Opini Surat Kabar Harian Solopos Edisi Februari 2015”, Skripsi. Surakarta: Universitas Muhammadiyah Surakarta.

Yuwono, Untung 2005.Pesona Bahasa: Langkah awal memahami Linguistik. Jakarta: Gramedia

Solopos, 01 Oktober 2019. “Teruskan Aksi Heroik”. Solopos. hlm. 9.

Solopos, 02 Oktober 2019. "Menantang Benteng Gerendel”. Solopos. hlm. 12

Solopos, 03 Oktober 2019. "Seri Sudah Serasa Menang”. Solopos. hlm. 12

Solopos, 04 Oktober 2019. "Skomina dianggap Terpengaruh Camp Nou". Solopos. hlm. 12

Solopos, 08 Oktober 2019. "Tinggal Menanti Keputusan Spalletti". Solopos. hlm. 12

Solopos, 10 Oktober 2019. "Indonesia Didenda Rp 643 Juta". Solopos. hlm. 12

Solopos, 14 Oktober 2019. "Saatnya Merespons”. Solopos. hlm. 12

Solopos, 15 Oktober 2019. "Modric dan Bale Cedera”. Solopos. hlm. 12

Solopos, 16 Oktober 2019. "Lee Mengejutkan, Felix Berpulang”. Solopos. hlm. 12

Solopos, 18 Oktober 2019. "Berat Tanpa Pogba dan De Gea”. Solopos. hlm. 12

Solopos, 22 Oktober 2019. "Berkat Formasi Tak Biasa”. Solopos. hlm. 12 Solopos, 23 Oktober 2019. "Melawan Rekor Buruk Tandang di Eropa". 
40 | ESTETIK : Jurnal Bahasa Indonesia, vol. 3, no. 1, 2020

Solopos. hlm. 12

http://www.solopos.com, diunduh tanggal 03 November 2019. 